\title{
Computational Evaluation of Novel Schiff base Complexes as Anti-Dengue and Anti-cancer Agent
}

\author{
M. SEETHALAKSHMI ${ }^{1}$ and T. PETER AMALADHAS ${ }^{1 *}$ \\ 'PG and Research Department of Chemistry, V.O. Chidambaram College, \\ Tuticorin, Affiliated to Manonmaniam Sundaranar University, Tirunelveli, India. \\ *Corresponding author E-Mail: peteramaladhas@gmail.com \\ http://dx.doi.org/10.13005/ojc/340330
}

(Received: January 08, 2018; Accepted: May 11, 2018)

\begin{abstract}
A neoteric Schiff base ligand, 4-(4-chlorobenzylideneamino)-N-(4-(4-chlorobenzy lideneamino)phenyl)benzamide (L1), and its $\mathrm{Co}(\mathrm{II}), \mathrm{Ni}(\mathrm{II})$ and $\mathrm{Cu}(\mathrm{II})$ complexes were synthesized. The structure of ligand L1 and its complexes were confirmed by NMR, FT-IR, UV-Vis., EPR and El- mass techniques. The synthesized complexes were docked with human DNA topoisomerase I (PDB: 1SC7) and Dengue NS3 protease-helicase (PDB ID: 2VBC) using Auto Dock vina and Discovery studio software. The binding which is enclosed in a box having number of grid points in $x \times y \times z$ directions of $40 \times 40 \times 40$ and a grid spacing of $0.35 \AA$. The binding energy values of the $\mathrm{Co}(\mathrm{II}), \mathrm{Ni}(\mathrm{II})$ and $\mathrm{Cu}(\mathrm{II})$ complexes were respectively $-12.4,-13.7$ and $-13.0 \mathrm{kcal} \mathrm{mol}^{-1}$ towards NS3 protease-helicase and $-16.8,-10.4$ and $-15.1 \mathrm{kcal} \mathrm{mol}^{-1}$ towards human DNA topoisomerase I. These results established that the synthesized compounds could act as a potential Anti-Dengue and Anticancer agent.
\end{abstract}

Keywords: Schiff base ligand, Anti-dengue drug, docking, human DNA topoisomerase I, NS3 protease-helicase.

\section{INTRODUCTION}

Research on interactions of the metal complexes especially $\mathrm{Co}(\mathrm{II}), \mathrm{Ni}(\mathrm{II})$ and $\mathrm{Cu}(\mathrm{II})$ with DNA helps to get a immense knowledge about development of novel chemotherapeutics and medicines ${ }^{1-4}$. The interactions of metal complexes with DNA usually cause damage in cancer cells ${ }^{5-7}$. Dengue virus basically belongs to Flavivirus genus and is a member of Flaviviridae family ${ }^{8,9}$. The major source of the dengue virus development is human and monkey. Usually dengue affected humans have severe flu, fever, body pain like symptoms and body temperature almost reaches $40{ }^{\circ} \mathrm{C}$ which makes human to be critical. Severe headache, flushing of face and rashes in skin are the extreme symptoms of Dengue fever and this severe condition is said to be Dengue Hemorrhagic Fever (DHF) and Dengue Shock Syndrome (DSS) ${ }^{10,11}$. It is not possible to do the all experiment on the interaction of drugs towards the targeting molecule in low cost. Docking is the only way to give the corresponding exact results 
of newly synthesized drugs towards the targeting molecule ${ }^{12-18}$. Auto dock vina and discovery studio is a useful tool to study the interaction between the ligand and the target molecule. This software helps to determine the binding mode, binding affinity and also the exact stable configuration of the ligand, which binds with the receptor ${ }^{19-22}$. Using this docking study, we can understand the coordination mode and the binding nature. It will help to design a good drug for the disease ${ }^{23-26}$. In this present work, a neoteric Schiff base ligand, 4-(4-chlorobenzylideneamino)-N(4-(4-chlorobenzylideneamino) phenyl)benzamide (L1) and $\mathrm{Co}(\mathrm{II}), \mathrm{Ni}(\mathrm{II})$ and $\mathrm{Cu}(\mathrm{II})$ complexes of $\mathrm{L} 1$ were synthesized. The synthesized ligand and its complexes were treated with human DNA topoisomerase I (PDB: 1SC7) and Dengue NS3 protease-helicase (PDB ID: 2VBC) by docking.

\section{MATERIALS AND EXPERIMENTAL METHODS}

All the chemicals which were used in the present work were purchased from commercial sources and were used without further purification. 4,4'-diaminobenzanilide, p-chlorobenzaldehyde, cobalt chloride hexahydrate $\left(\mathrm{CoCl}_{2} \cdot 6 \mathrm{H}_{2} \mathrm{O}\right)$, nickel chloride hexahydrate $\left(\mathrm{NiCl}_{2} \cdot 6 \mathrm{H}_{2} \mathrm{O}\right)$ and copper chloride dihydrate $\left(\mathrm{CuCl}_{2} \cdot 6 \mathrm{H}_{2} \mathrm{O}\right)$ were bought from Sigma Aldrich, USA and utilized as received. Solvents used in the present research were purchased from Merck and were used without further purification.

${ }^{1} \mathrm{H}-\mathrm{NMR}$ spectrum of the synthesized Schiff base ligand L1 was recorded in DMSO $\left(d_{6}\right)$ and TMS is used as an internal standard on a Bruker Advance DRX 300 FT-NMR instrument. Vibrational spectra of the ligand and complexes were recorded in JASCO/FT-IR410 spectrometer in the range of
$4000-400 \mathrm{~cm}^{-1}$ at $16 \mathrm{scans} / \mathrm{min}$. Potassium bromide disc method was employed for sample preparation. Electronic spectra of the complexes dissolved in DMSO were recorded using Perkin Elmer Lambda25 UV-Vis. spectrophotometer in the range of 200-800 $\mathrm{nm}$. The Electron Ionization Mass spectra of the ligand was recorded using JEOL DX-303 El mass spectrometer, and X- band EPR spectra of the copper complex in DMSO was recorded on Varian E-4 X-band spectrometer using DPPH as the g-marker at room temperature at Indian Institute of Technology, Madras, India.

\section{EXPERIMENTAL}

Synthesis of 4-(4-chlorobenzylideneamino)-N-(4-(4chlorobenzylideneamino)phenyl) benzamide (L1)

A hot solution of $1.136 \mathrm{~g}(5 \mathrm{mmol})$ 4,4'-diaminobenzanilide in $10 \mathrm{~mL}$ methanol was added drop wise to a hot stirring solution of $1.4057 \mathrm{~g}$ (10 mmol) p-chlorobenzaldehyde in $10 \mathrm{~mL}$ methanol. The above mixture was stirred under reflux condition for 5 hours (Scheme-1). A yellow colour solid mass appeared was filtered, washed with dimethyl ether several times and dried in in vacuo at room temperature.

\section{Synthesis of Cobalt(II), Nickel(II) and Copper (II) complexes of L1}

To the hot stirring solution of the $0.9447 \mathrm{~g}$ (2 mmol) Schiff base ligand L1 in $20 \mathrm{~mL}$ of methanol, the corresponding metal(II) chlorides $\left[\mathrm{CoCl}_{2} \cdot 6 \mathrm{H}_{2} \mathrm{O}\right.$ $(0.237 \mathrm{~g}, 1 \mathrm{mmol}), \mathrm{NiCl}_{2} \cdot 6 \mathrm{H}_{2} \mathrm{O}(0.2379 \mathrm{~g}, 1 \mathrm{mmol})$ and $\left.\mathrm{CuCl}_{2} .2 \mathrm{H}_{2} \mathrm{O}(0.170 \mathrm{~g}, 1 \mathrm{mmol})\right]$ in $20 \mathrm{~mL}$ of methanol were added, stirred under reflux for $6 \mathrm{~h}$ (Scheme-2). Then the product obtained was filtered, washed and dried in vacuo at room temperature.

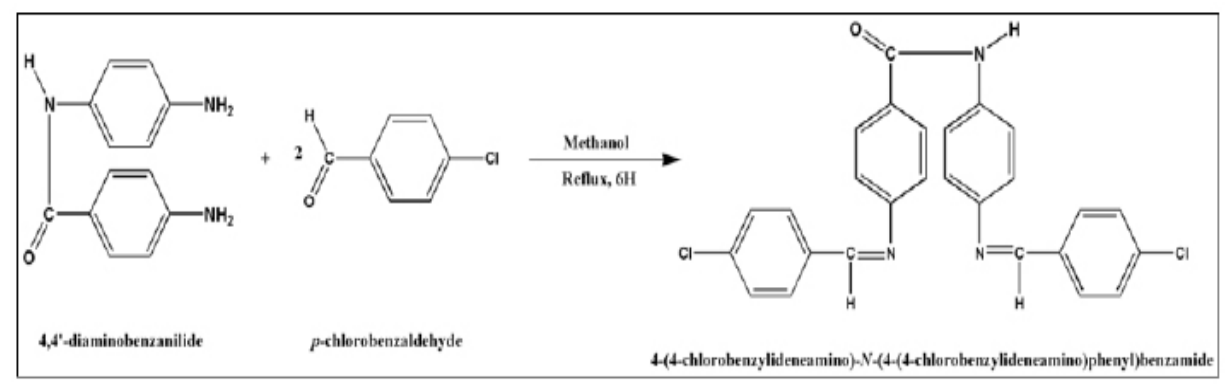

Scheme 1. Synthesis of Schiff base Ligand L1 


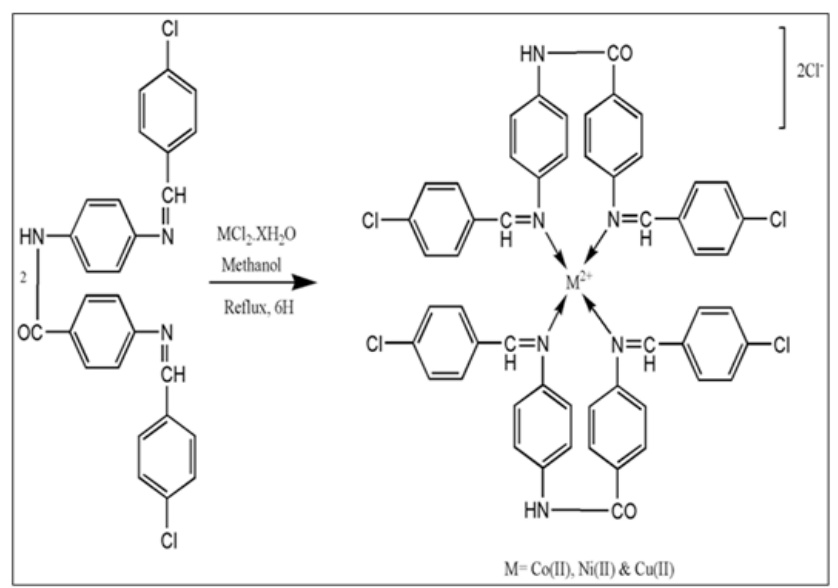

Scheme 2. Synthesis of Schiff base metal complexes

\section{Molecular docking study}

Human-DNA-Topo-I complex (PDBID:

$1 \mathrm{SC7})^{27}$ and Dengue NS3 protease-helicase (PDB ID: $2 V_{B C}{ }^{28}$ were obtained from Protein Data Bank (http://www.rcsb.org/pdb). Metal complexes were converted into PDB format by using Mercury software ${ }^{29}$. The 'receptor' (DNA/Dengue) and 'ligand' (metal complexes) files were docked using Auto Dock Tools. The hetero atoms such as water molecules and excess ligand were removed. The polar hydrogen atoms and Kollman charges were added to the receptor (DNA/Dengue) molecule to investigate the binding nature. The binding which was enclosed in a box have number of grid points in $x \times y \times z$ directions of $40 \times 40 \times 40$ and a grid spacing of $0.35 \AA$. The docking studies were conducted using
Auto DockTools (ADT) version 1.5.4 and finalized by Auto Dock vina program ${ }^{30}$. The docked structures were exposed using Discovery studio software.

\section{RESULTS AND DISCUSSION}

\section{${ }^{1} \mathrm{H}$-NMR Spectral Studies and Electron Impact Mass Spectral analysis}

In the ${ }^{1} \mathrm{H}$ NMR spectrum of the ligand $\mathrm{L} 1$, which is provided in the Fig. 1 there is a signal at 9.61 ppm attributed to amido proton of benzanilide group present in the ligand $\mathrm{L} 1^{31}$. The signal for azomethine proton appeared as a small peak at $8 \mathrm{ppm}^{32}$. The multiplet in the region 6.05-7.55 ppm represents the protons present in the aromatic moiety.

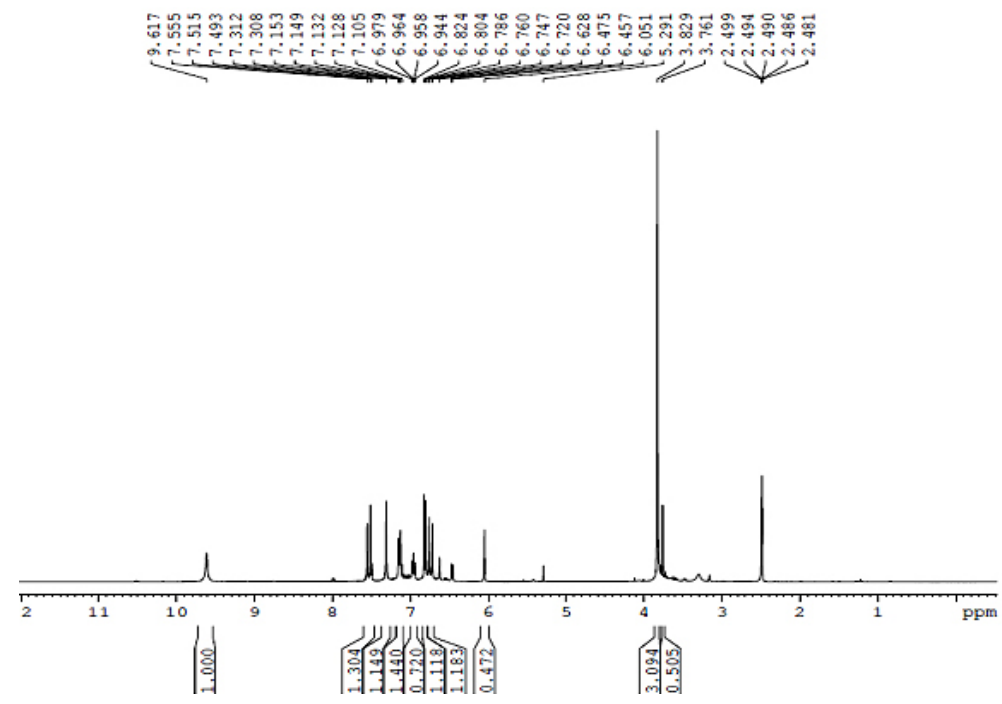

Fig. 1. ${ }^{1} \mathrm{H}-\mathrm{NMR}$ Spectra of L1 
The Electron Ionization mass spectrum of the Schiff base ligand L1 is given in the Fig. 2 . The molecular ion $\mathrm{M}^{+}$peak is present at 470.9364 , which is corresponding to the molecular weight of the ligand $\mathrm{L} 1$. In addition there is an $\left(\mathrm{M}^{+}+2\right)$ isotopic peak at 472.9053 . The peaks at 367.9976, 326.0706, 311.0307, 241.8728, 207.0274, 152.0043 and 91.0319 correspond to various fragments of the ligand.

\section{FT-IR Spectral Studies}

The FT-IR spectrum of the Schiff base ligand L1 and its complexes were represented in the Fig. 3. The FT-IR spectra of the ligand L1 exhibits a band at $1592 \mathrm{~cm}^{-1}$, which is attributed to imino stretching frequency of the Schiff base ligand ${ }^{33}$.
The strong peak at $3354 \mathrm{~cm}^{-1}$ is the characteristic $\mathrm{N}-\mathrm{H}$ stretching frequency of the secondary amide group of 4,4-diaminobenzanilide part of the ligand. To study the binding mode of the ligand to the metal in the complexes, the IR spectrum of the free ligand and its complexes were compared. The band near $1592 \mathrm{~cm}^{-1}$ is shifted to lower frequencies in complexes. This clearly indicates the coordination of the imino-nitrogen of the ligand to the metal center ${ }^{34}$. Further the IR spectra of the complexes show some new sharp signals in the region 467 $\mathrm{cm}^{-1}, 437 \mathrm{~cm}^{-1}$ and $465 \mathrm{~cm}^{-1}$ for $\mathrm{Co}(\mathrm{L} 1)_{2}, \mathrm{Ni}(\mathrm{L} 1)_{2}$ and $\mathrm{Cu}(\mathrm{L} 1)_{2}$ complexes respectively, which corresponds to metal-nitrogen stretching formed by the coordination of imino nitrogen of the ligand with the metal centers.

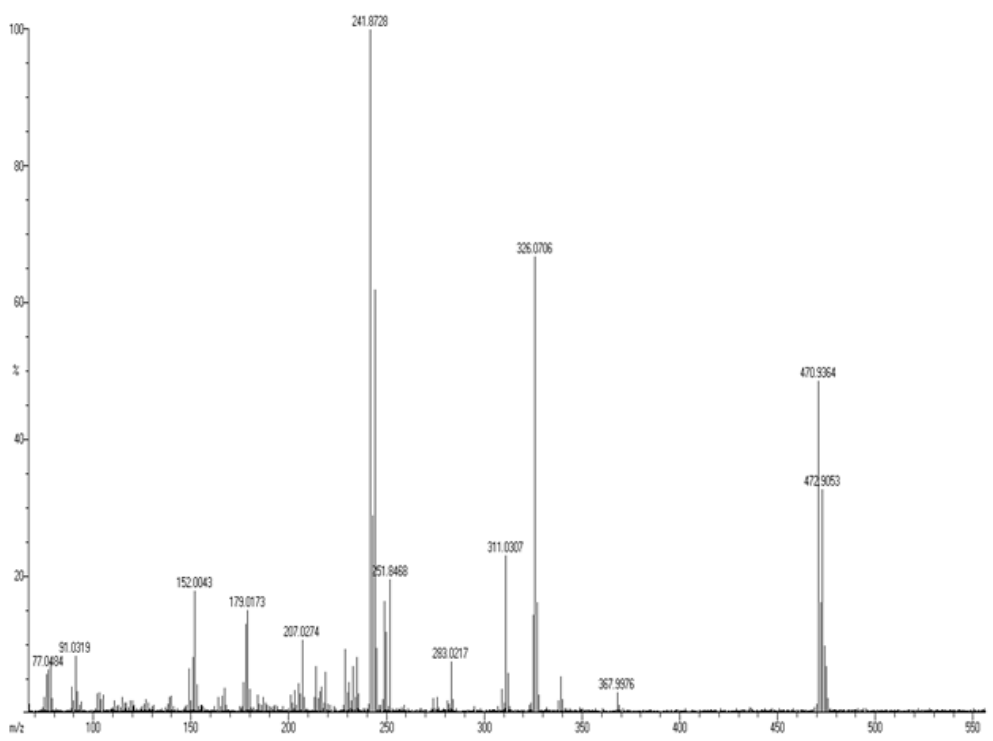

Fig. 2. El- Mass spectra of L1

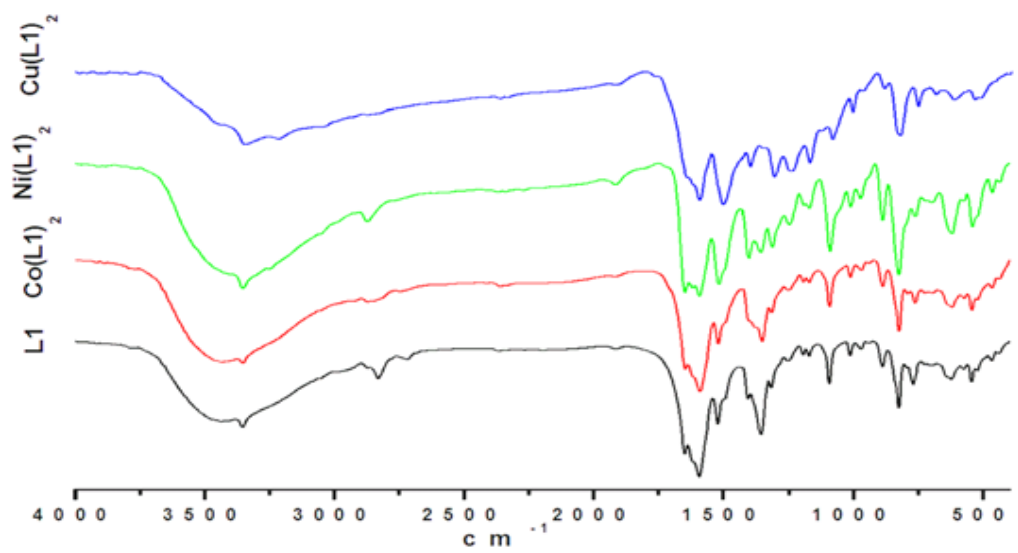

Fig. 3. FT-IR Spectra of Schiff base ligand L1 and its complexes 


\section{Electronic spectral analysis}

The electronic spectra of complexes $\mathrm{Co}(\mathrm{L} 1)_{2}, \mathrm{Ni}(\mathrm{L} 1)_{2}$ and $\mathrm{Cu}(\mathrm{L} 1)_{2}$ are recorded in the range of $200 \mathrm{~nm}-800 \mathrm{~nm}$ in DMSO and were provided in Fig. 4. The spectral details below $350 \mathrm{~nm}$ are similar for all the complexes and they are corresponding to the transitions $\left(\pi \rightarrow \pi^{*}\right.$ and $\left.n \rightarrow \pi^{*}\right)$ of benzene ring and non-bonding electrons present on the nitrogen of azomethine group in the Schiff base complexes $^{35}$. In the electronic spectra of the cobalt complex, the band around $380 \mathrm{~nm}$ is assigned to $\mathrm{LMCT}^{36}$ transition while the $\mathrm{d}-\mathrm{d}$ band observed in the lower energy region around $430 \mathrm{~nm}$ is assigned to the combination of ${ }^{2} \mathrm{~B}_{1 \mathrm{~g}} \rightarrow{ }^{1} \mathrm{~A}_{1 \mathrm{~g}}$ and ${ }^{1} \mathrm{~B}_{1 \mathrm{~g}} \rightarrow{ }^{2} \mathrm{Eg}$ transitions. This transition represents a square planar geometry for cobalt complex ${ }^{37-38}$. In the electronic spectrum of the nickel complex, the band around $360 \mathrm{~nm}$ is assigned to LMCT transition. Additionally a broad band observed in the lower energy region around $370-410 \mathrm{~nm}$ is assigned to $\mathrm{d}-\mathrm{d}\left({ }^{1} \mathrm{~A}_{1 \mathrm{~g}} \rightarrow{ }^{1} \mathrm{~B}_{1 \mathrm{~g}}\right)$ transition. This transition represents the square planar geometry for nickel complex ${ }^{39}$. The electronic spectrum of copper complex shows $d$-d band at $450 \mathrm{~nm}$, which is attributed to the combination of ${ }^{2} \mathrm{~B}_{1 \mathrm{~g}} \rightarrow{ }^{2} \mathrm{E}_{\mathrm{g}}$ and ${ }^{2} \mathrm{~B}_{1 \mathrm{~g}} \rightarrow{ }^{2} \mathrm{~B}_{2 \mathrm{~g}}$ transitions. This give the evidence for the distorted square planar geometry for d9 $\mathrm{Cu}(\mathrm{II})$ system $^{40}$.

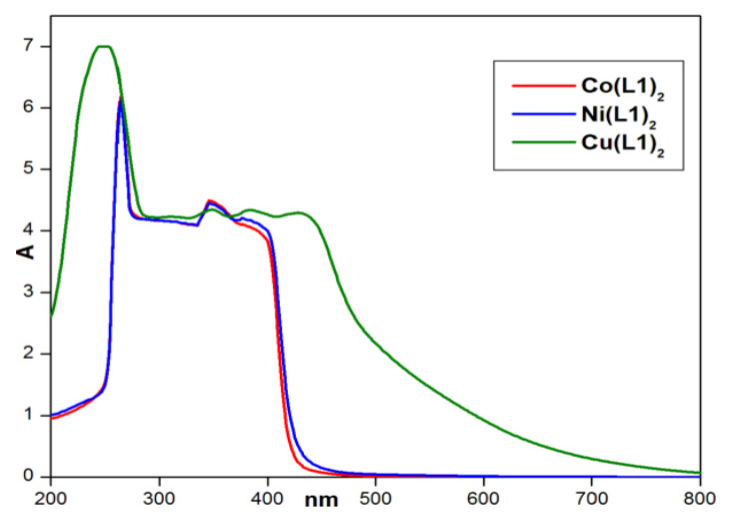

Fig. 4. UV-Vis Spectra of Schiff base complexes

\section{EPR spectral analysis}

The EPR spectra of copper complex give useful information in studying the metal ion environment. In the EPR spectrum of the copper complex $\mathrm{Cu}(\mathrm{L} 1)_{2}$ there is an isotropic signal, without any hyperfine splitting, with $g_{\text {iso }}=2.12$ as shown in the Fig. 5. When comparing the $g_{\text {iso }}$ value of the copper complex with the $g$ value of free electron
(2.0023) indicate that there is an increase in the covalent nature of the bonding between the metal ion and the ligand molecule ${ }^{41}$. Isotropic lines are usually appeared due to the occupancy of the unpaired electron in a degenerate orbital in square planar geometry.

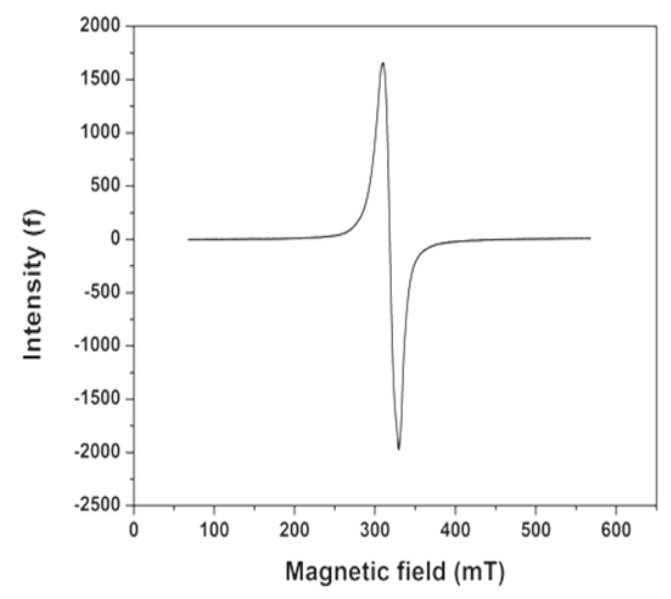

Fig.5. EPR Spectrum of $\mathrm{Cu}(\mathrm{L} 1)_{2}$

Molecular docking with human DNA topoisomerase I

Human DNA topoisomerase I was the selective targeting area for synthesizing the anticancer drug ${ }^{42}$. The molecular docking of $\mathrm{Co}$ (II), Ni (II) and Cu(II) complexes were performed to determine the binding affinity value and the selected binding residue, along with the sterically suitable conformations. The low value of the binding energy shows the more effective binding affinity between the 'receptor'(DNA) and the 'ligand'(complex) molecules. The various conformations of docked molecular complexes were analyzed in terms of binding energy, hydrogen bonding and hydrophobic interaction between receptors and the acceptor. More negative value of the relative binding values suggests that the interaction between the DNA and ligand is so strong, due to the extended aromatic ring. Phenyl ring has higher free binding energy which gives a better binding affinity value comparing with a compound containing bipyridyl ring. In these work mononuclear complexes give better results towards the HDNA. The binding energy values of the $\mathrm{Co}(\mathrm{II}), \mathrm{Ni}(\mathrm{II})$ and $\mathrm{Cu}(\mathrm{II})$ complexes were respectively $-16.8,-10.4$ and -15.1 $\mathrm{kcal} \mathrm{mol}^{-1}$ towards human DNA topoisomerase I. This shows that Cobalt(II) and Copper(II) molecule easily bind with the DNA helix and the Nickel(II) complex preferred to bind with the outermost protein's amino acid residue. The binding values were shown in the Table 1, 2 and 3 and the docked images were shown in Figure 6. 


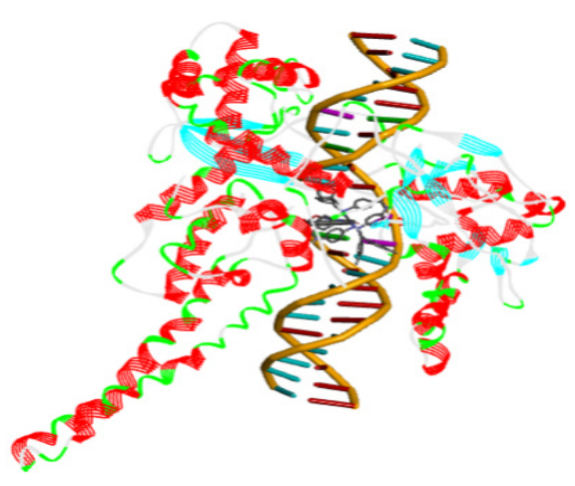

(a)

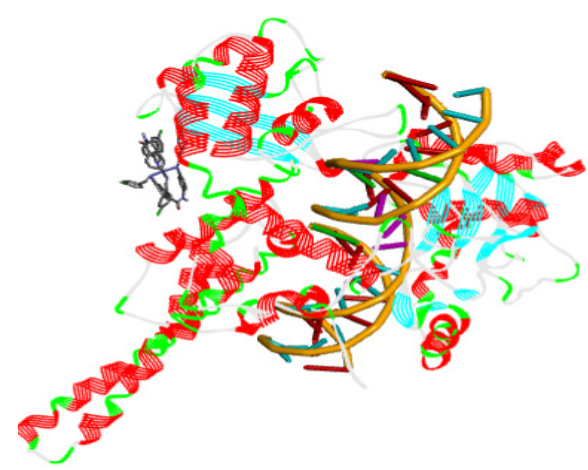

(c)

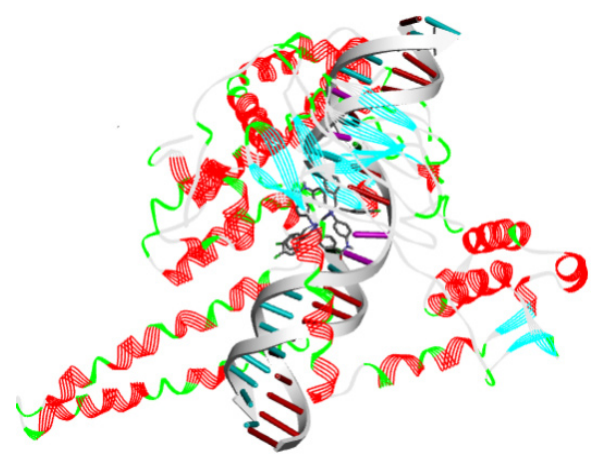

(e)

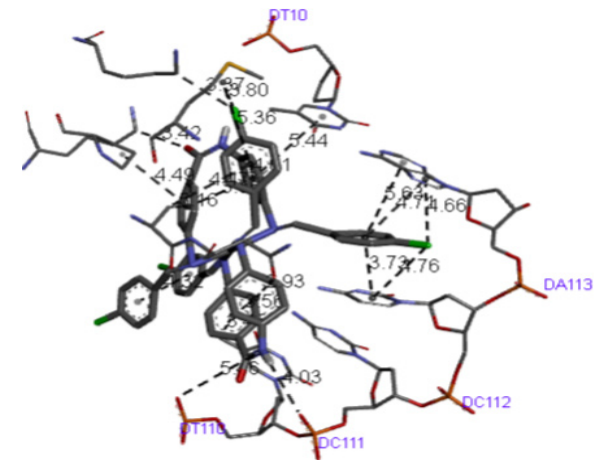

(b)

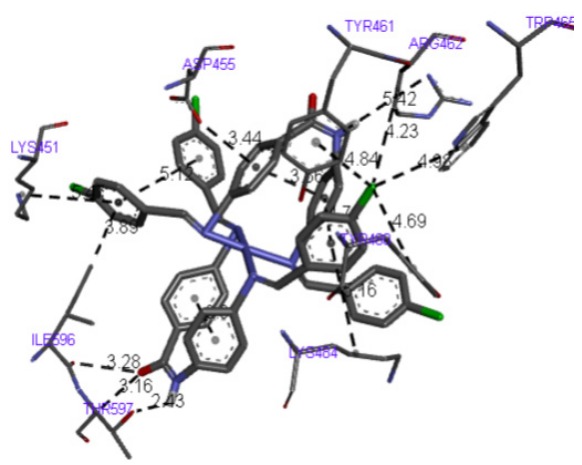

(d)

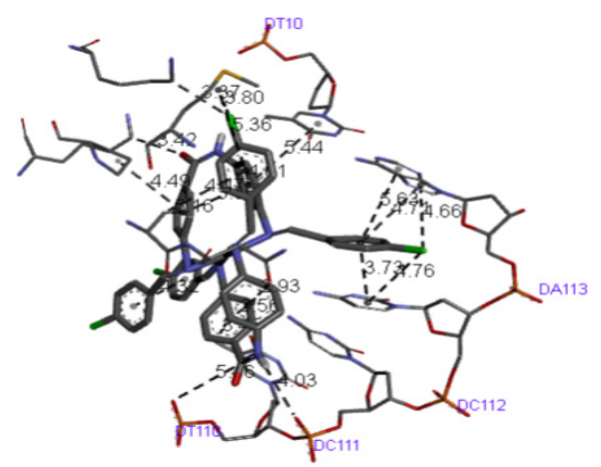

(f)

Figure 6 (a), (c) and (e) demonstrate the binding of $\mathrm{Co}$ (II), $\mathrm{Ni}(\mathrm{II})$ and $\mathrm{Cu}$ (II) complexes with active site of human DNA topoisomerase I, and (b), (d) and (f) demonstrate the binding of $\mathrm{Co}$ (II), $\mathrm{Ni}$ (II) and $\mathrm{Cu}$ (II) complexes with selective Nucleotide of human DNA topoisomerase I

Molecular docking with NS3 protease-helicase

NS3 protease-helicase (dengue virus) is a very important target area which should be docked. Cobalt(II), Nickel(II) and Copper(II) complexes exhibit very low binding energy value, it means that complexes having very high binding affinity towards the NS3 protease-helicase. The values of the binding energy in various levels are present in table 1, 2 \& 3 The distance between the selected receptor to targeted molecule is also low. The binding energy values of the $\mathrm{Co}(\mathrm{II}), \mathrm{Ni}(\mathrm{II})$ and $\mathrm{Cu}(\mathrm{II})$ complexes were $-12.4,-13.7$ and $-13.0 \mathrm{kcal} \mathrm{mol}^{-1}$ respectively. The binding interactions were shown in Fig. 7. From the theoretical point of view these complexes are considered to be a good anti-dengue drug. 


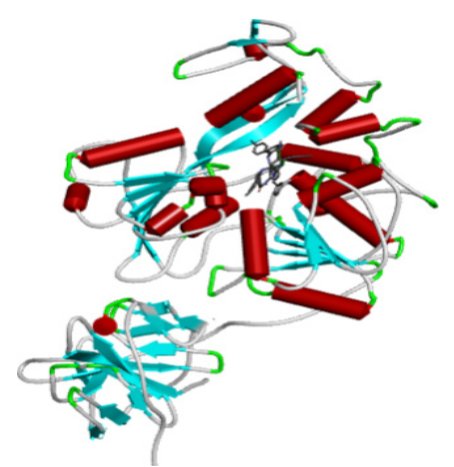

(a)

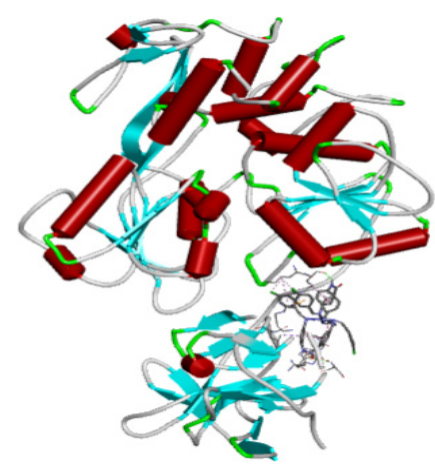

(c)

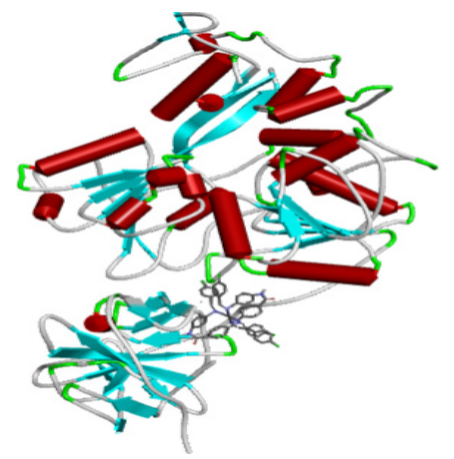

(e)

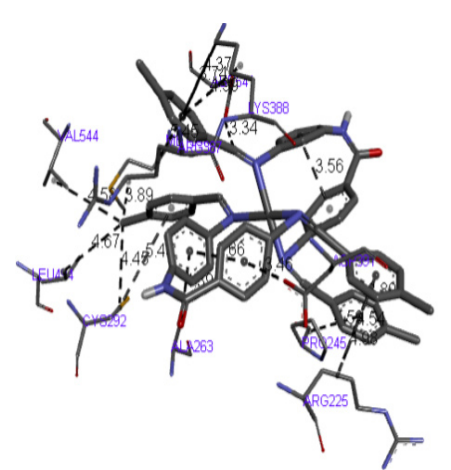

(b)

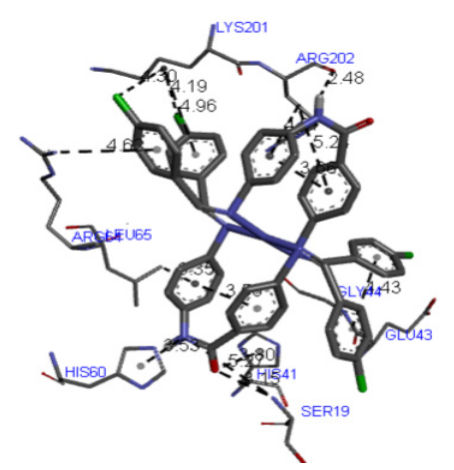

(d)

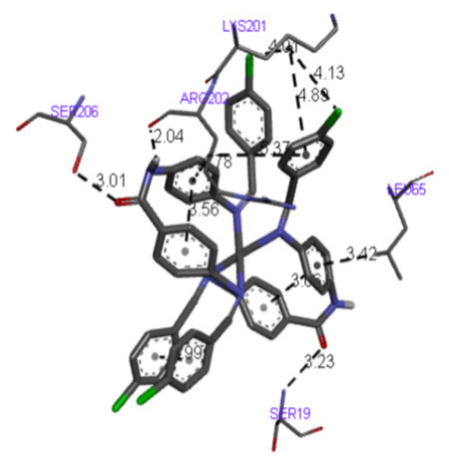

(f)

Fig. 7. (a) (c) and (e) demonstrate the binding of $\mathrm{Co}$ (II), $\mathrm{Ni}$ (II) and $\mathrm{Cu}$ (II) complexes with active site of NS3 protease-helicase, and (b), (d) and (f) demonstrate the binding of $\mathrm{Co}(\mathrm{II}), \mathrm{Ni}(\mathrm{II})$ and $\mathrm{Cu}(\mathrm{II})$ complexes with selective Amino acid residue of NS3 protease-helicase

\section{CONCLUSION}

A new Schiff base ligand which contains several phenyl rings and its $\mathrm{Co}(\mathrm{II}), \mathrm{Ni}(\mathrm{II})$ and $\mathrm{Cu}(\mathrm{II})$ complexes were synthesized. The formation of the ligand and its metal complexes were confirmed by various spectroscopic techniques. The docking studies were carried out using synthesized metal complexes with human DNA topoisomerase I
(PDB: 1SC7) and Dengue NS3 protease-helicase (PDB ID: 2VBC) using Auto Dock vina and Discovery studio software. The binding energy values of the $\mathrm{Co}(\mathrm{II}), \mathrm{Ni}(\mathrm{II})$ and $\mathrm{Cu}(\mathrm{II})$ complexes were respectively $-12.4,-13.7$ and $-13.0 \mathrm{kcal}^{\mathrm{mol}^{-1}}$ towards NS3 protease-helicase and $-16.8,-10.4$ and $-15.1 \mathrm{kcal}$ $\mathrm{mol}^{-1}$ towards human DNA topoisomerase I, which showed that these types of compounds can be act as an potential Anti-Dengue and Anticancer agent 


\section{ACKNOWLEDGEMENT}

The authors are thankful to Indian Institute of Technology, Madras, India for El-mass and EPR spectral analysis and also Dr. S. Gnanavel, Research and Project Centre for Chemical and Biological Science for docking study, Salem, India.

\section{REFERENCES}

1. Sigman, D. S.; Mazumder, A.; Perrin, D. M. Chem. Rev. 1993, 93(6), 2295-2316.

2. Jamieson, E. R.; Lippard, S. J. Chem. Rev., 1999, 99(9), 2467-2498.

3. Liu, H. K.; Sadler, P. J. Acc. Chem. Res., 2011, 44(5), 349-359.

4. Leung, M. H. M.; Harada, T.; Kee, T. W. Curr. Pharm. Des., 2013, 19(11), 2070-2083.

5. Alagesan, M.; Bhuvanesh, N. S. P.; Dharmaraj, N. Dalton Trans., 2014, 43(16), 6087-6099.

6. Shao, J.; Ma, Z. Y.; Li, A.; Liu, Y. H.; Xie, C. Z.; Qiang, Z.Y.; Xu, J.Y. J. Inorg. Biochem., 2014, 136, 13-23.

7. Mjos, K. D.; Orvig, C. Chem. Rev., 2014, 114(8), 4540-4563.

8. Wichapong, K.; Nueangaudom, A.; Pianwanit, S.; Sippl, W.; Kokpol, S. Trop. Biomed., 2013, 30(3), 388-408.

9. Murphy, F.A.; Mahy, B.W.J.; van Regenmortel, M.H.V. Encycl. Virol., 2008, 140-148.

10. Mastrangelo, E.; Milani, M.; Bollati, M.; Selisko, B.; Peyrane, F.; Pandini, V.; Sorrentino, G.; Canard, B.; Konarev, P.V.; Svergun, D.I.; de Lamballerie, X.; Coutard, B.; Khromykh, A.A.; Bolognesi, $M$. J. Mol. Biol., 2007, 372(2), 444-455.

11. Byrd, C.M.; Grosenbach, D.W.; Berhanu, A.; Dai, D.; Jones, K.F.; Cardwell, K.B.; Schneider, C.; Yang, G.; Tyavanagimatt, S.; Harver, C.; Wineinger, K. A.; Page, J.; Stavale, E.; Stone, M. A.; Fuller, K. P.; Lovejoy, C.; Leeds, J. M.; Hruby, D. E.; Jordan, R. Antimicrob. Agents Chemother., 2013, 57(4), 1902-1912.

12. Noble, C.G.; She, C.C.; Chao, A.T.; Shi P.Y. J. Vir., 2012, 86(1), 438-446.

13. Madhavi Sastry, G.; Adzhigirey, M.; Day, T.; Annabhimoju, R.; Sherman, W. J. Comput. Aided Mol. Des., 2013, 27(3), 221-234.

14. Bas, D.C.; Rogers, D. M.; Jensen, J. H. Proteins Struct. Funct. Genet., 2008, 73(3), 765-783.

15. Li, H.; Robertson, A. D.; Jensen, J.H. Proteins. 2005, 61 (4), 704-721

16. Irwin, J.J.; Shoichet, B.K. J. Chem. Inf. Model.,
2005, 45 (1), 177-182.

17. Greenwood, J. R.; Calkins, D.; Sullivan, A.P.; Shelley, J. C. J. Comput. Aided Mol. Des., 2010, 24 (6-7), 591-604.

18. Greco, M. N.; Hawkins, M. J.; Powell, E. T.; Almond, H. R.; Garavilla, L.; Hall, J.; Minor, L. K.; Wang, Y.; Corcoran, T.W.; Cera, E. D.; Cantwell, A. M.; Savvides, S.N.; Damiano, B.P.; Maryanoff , B. E. J. Med .Chem., 2007, 50(8), 1727-1730.

19. Iijima, K.; Katada, J.; Yasuda, E.; Uno, I.; Hayashi, Y. J. Med. Chem., 1999, 42(2), 312-323.

20. Aoyama, Y.; Uenaka, M.; Kii, M.; Tanaka, M.; Konoike, T.; Hayasaki- Kajiwara, Y.; Naya, N.; Nakajima, M. Bioorg. Med. Chem., 2001, 9(11), 3065-3075.

21. Aoyama, Y.; Uenaka, M.; Konoike, T.; Hayasaki-Kajiwara, Y.; Naya, N.; Nakajima, M. Bioorg. Med. Chem. Lett., 2001, 11(13), 1691-1694.

22. Aoyama, Y.; Konoike ,T.; Kanda, A.; Naya, N.; Nakajima, M. Bioorg. Med. Chem.Lett., 2001, 11(13), 1695-1697.

23. Maruoka, H.; Muto, T.; Tanaka, T.; Imajo, S.; Tomimori, Y.; Fukudaa, Y.; Nakatsuka, T. Bioorg. Med. Chem. Lett., 2007, 17(12), 3435-3439.

24. Wawer, M.; Bajorath, J. J .Chem. Inf. Model., 2010, 50(8), 1395-1409.

25. Thangapandian, S.; John, S.; Sakkiah, S.; Lee, K. L. J. Chem. Inf. Model., 2011, 51(1), 33-44.

26. Lie, M. A.; Thomsen, R.; Pedersen, C. N. S.; Schiøtt B.; Christensen, M. H. J. Chem. Inf. Model., 2011, 51(4), 909-917.

27. Bujacz, A. ActaCrystallogr., D. 2012, 68(10), 1278-1289.

28. Mirza, S.B., Salmas R.E., Fatmi M.Q.and Durdagi S. J, mol graph model., 2016, 66, 99-107.

29. Macrae, C. F.; Edgington, P. R.; McCabe, P.; Pidcock, E.; Shields, G. P.; Taylor, R.; Towler, M.; van de Streek, J. J. Appl. Crystallogr., 2006, 39, 453-457 
30. Trott, O.; Olson, A. J. J. Comput. Chem., 2010, 31(2), 455-461.

31. Abdulghani, A. J.; Mohuee, S.K. J Chem Bio Phy Sci., 2016, 6(2), 579-595.

32. Patel, K. V.; Bhattacharya, P. K. Ind. J. Chem. 1982, 21(12), 1110-1112.

33. Singh, D. P.; Vandna Malik; Krishan Kumar; Chetan Sharma ; Aneeja, K.R. Spectrochim., A. 2010, 76(1), 45-49.

34. Raman, N.; Sobha, S. Spectrochim. Acta., A. 2012, 85(1), 223-234.

35. Ramesh, R.; Maheswaran, S. J.Inorg. Biochem., 2003, 96(4), 457-462.

36. Ortiz, B.; Park, S. M. Bull. korean Chem.Soc., 2000, 21(4), 405- 411.
37. Shakir, M.; Nasam, O.S.M.; Mohamed A. K.; Varkey, S.P. Polyhedron., 1996, 15(8), 12831287.

38. Chem, L. S.; Cummings, S.C. Inorg. Chem., 1978, 17(9), 2358-2361.

39. Kirchhoff, J. R.; GamacheJr, R. E.; Blaskie, M. W.; Del Paggio, A. A.; Lengel, R. K.; McMillin, D.R. Inorg. Chem., 1983, 22(17), 2380-2384.

40. Natarajan, C.; Tharmaraj, P.; Murugesan, R. J. Coord. Chem., 1992, 26(3), 205-213.

41. Raman, N.; Dhaveedhu Raja, J.; Shakthivel, A. J. Chem. Sci., 2007, 119(4), 303-310.

42. Pommier, Y. Nat. Rev. Cancer., 2006, 6(10), 789-802. 